s Pavlov, I., Conditioned Reftexes (Oxford University Press, New York, 1927).

- Sokolov, E., Perception and the Conditioned Reflex (Macmillan, New York, 1963)

${ }^{10}$ Weinberger, N. M., and Goodman, D. A., Behav. Res. Meth. und Instr., 1, $192(1969)$.

${ }_{11}$ Thompson, H. F., and Spencer, W. A., Psychol. Rev., 173, 16 (1966).

12 Graham, F., and Clifton, R., Psychol. Bull., 65, 366 (1966).

${ }^{13}$ Davis, R. (., Buchwald, A. M., and Frankmann, R., Psychol. Mon., 405 $(1955)$.

${ }^{14}$ Lynn, R.. Attention, Arousal and the Orienting Reaction (Pergamon, New York, 1966)

${ }^{15}$ Belkin, D. A., Amer. Zool., 8, 775 (1968).

${ }^{16}$ Ursin, H., Wester, K., and Ursin, R., Electroenceph. Clin. Neurophysiol. 23, 41 (1987).

${ }_{17}$ Jasper, H. H., in Reticular Formation of the Brain (edit. by Jasper, H. H., et al. ), 319 (Churchill, London, 1958).

${ }^{18}$ Reiz, D., and McHugh, P., Amer. J. Physiol., 214, 601 (1968).

${ }^{19}$ Ursin, H., and Kaada, B. R., Exp. Neurol., 2, 109 (1960).

"Folkow, B., Buxe, K., and Sonnenschein, R., Acta Physiol. Scand., 6r, 327 (1966).

"Folkow, B., Nilsson, N., and Yonce, L., Acta Physiol. Scand., 70, 347 (1967).

${ }^{22}$ Andersen, H. T., A cta Physiol. Scand., 53, 23 (1961).

${ }^{23}$ Lund, G. F., and Dingle, H. J., J. Exp. Biol., 48, 265 (1968).

\section{Reproductive Cycle of a Neotropical Insectivorous Bat, Myotis nigricans}

REPRODUCTIVE patterns in bats fall into three main categories. A synchronous breeding season and monoestry is common in all holaretic bats ${ }^{1}$. Continual asynchronous breeding is found in some tropical bats of the families Desmodontidae 2 , Phyllostomatidae ${ }^{3}$, Pteropodidae, Emballonuridae and Molossidae 4 . In some palaeo. tropical bats seasonal polyoestry is the rule, with two synchronized breeding seasons each year ${ }^{4,5}$.

Because of the rigorous environment of the temperate zone, parturition in holarctic bats is largely limited to May, June and July, when temperatures are mild and food is abundant. Most of these temperate zone bats belong to the insectivorous family Vespertilionidae. Neotropical bats which breed continually are either sanguivorous or frugivorous and are probably never exposed to a shortage of food ${ }^{8}$.

Myotis nigricans, the first neotropical Vespertilionid whose reproduction has been studied, has a fourth type of reproductive cycle. These bats breed continually during most of the year but become reproductively quiescent for about 3 months during the latter part of the rainy season (Fig. 1).

We examined reproductive tracts of more than five hundred $M$. nigricans from September 1968 to September 1969. Animals were collected at wcekly intervals from roosts on Barro Colorado Island and the nearby town of Gamboa, Canal Zone. Pregnant females were taken in every month of the year except December. In November only a few pregnancies were noted, and all of those were near term in the first week of the month. After a 7 week period with no pregnancies, 63 per cent of the females collected during January were found to be pregnant. The first pregnancies were noted on January 3 and parturition began in the last week of February. This and subsequent observations lead us to believe that the gestation period for $M$. nigricans is near the 50-60 days reported for other members of the genus?. The three pregnancy peaks are about 3 months apart and our observations show that this is about the time needed for gestation and lactation of one litter. The animals tend to become less synchronized as the year proceeds, as shown by the fact that the peaks become progressively shorter, and there is always a certain number of pregnancies at any given time.

The curve for lactation is similar to that for pregnancy, but, of course, shows a time lag of one to two months. The total of the two percentages is sometimes more than one hundred, indicating animals that are both pregnant and laetating. Evidence for polyoestry consists of numer-

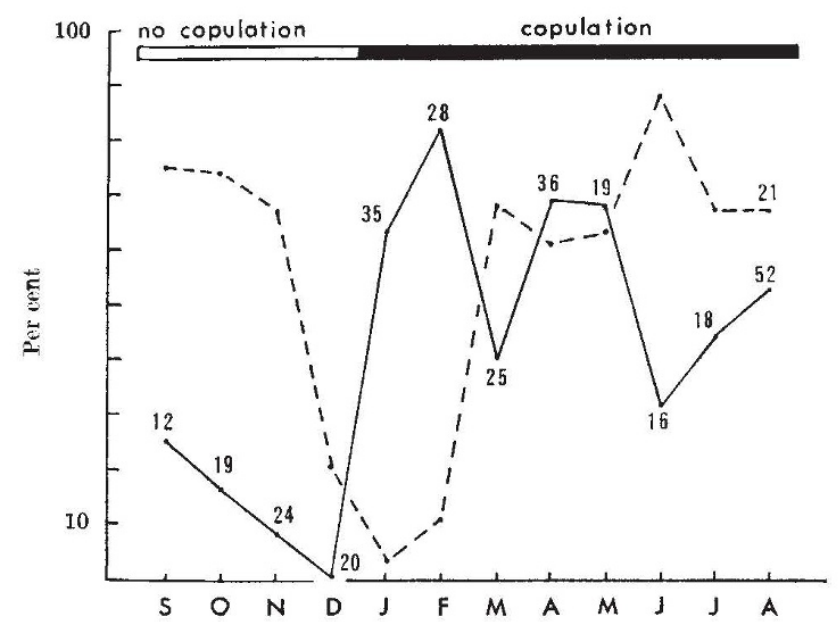

Fig. 1. Percentage of pregnant (_...) and lactating ( . - ) females in one year. The numbers are sample sizes.

ous individuals that were both pregnant and lactating, as well as continuous observations of banded individuals which produced at least two young during the year. This indicates post-partum oestrus at least occasionally, and we feel from other observations that it is the rule. This is the first conclusively demonstrated instance of polyoestry in the family Vespertilionidae, although there is suggestive evidence of its occurrence in a few Old World species of the genus Pipistrellus ${ }^{5,7}$.

If the gestation period is less than 60 days, it is hypo. thetically possible for a given female to produce four young in a year. We feel that because of individual variation in times of copulation, ovulation, fertilization, gestation period and post-partum oestrus, three is a more usual number.

The fact that no young are produced from December to March may relate to seasonality of the food supply. During the dry season (January-March), insect populations are probably lower than at other times of the year ${ }^{8}$. There is usually an insect bloom in April when the rains begin. It seems that the strategy of the bats is to wean the young at this time of year and to avoid weaning young at times of lowered food supply. Copulation must therefore cease around the middle of September, and the last young of the year are born in November and weaned in December. Copulation begins again in January (we observed it many times). The first young are born in March and weaned in April. The cues for this cycle are as yet unknown, but the eritical times are September and December, so that temperature and rain. fall would seem to be extremely unlikely. Photoperiod is a possibility, but changes at this latitude are slight ( $1 \mathrm{~h}$ and $3 \mathrm{~min}$ from summer solstice to winter solstice).

We thank the Smithsonian Tropical Research Institute. The US National Science Foundation provided J. S. F. with a grant.

Don E. WILSON James S. Findlex

Department of Biology,

University of New Mexico,

Albuquerque,

New Mexico 87106.

Received January 9, 1970.

${ }^{1}$ Cockrum, E. L., Trans. Kansas Acad. Sci., 58, 48 (1955).

${ }^{2}$ Wimsatt, W. A., and Trapido, H., Amer. J, A nat., 91, 415 (1952)

${ }_{3}$ Tamsitt, J. R., and Valdivieso, D., Amer. Mid. Nat., 73, 150 (1965).

Mutere, F. A., Acta Trop.,25, 97 (1968).

Brosset, A., Mammalia, 26, 176 (1962).

Tamsitt, J. R., and Valdivicso, D., Nature, 198, 104 (1963).

Asdell, S. A., Patterns of Mammalian Reproduction, 93 (Comstock, Ithaca, 1964).

$s$ Wilson, D. E., Mammalia (in the press). 